\title{
Impact of the oyster Crassostrea gigas on a microbial community in Atlantic coastal ponds near La Rochelle
}

\author{
Christine Dupuy ${ }^{1,2, *}$, Annie Pastoureaud ${ }^{1}$, Mireille Ryckaert ${ }^{1}$, \\ Pierre-Guy Sauriau ${ }^{1}$, Hélène Montanié ${ }^{2}$ \\ ${ }^{1}$ CNRS/IFREMER, Unité Mixte de recherche 10, Centre de Rechereche en écologie marine et aquaculture L'Houmeau, BP 5, \\ 17137 L'Houmeau, France \\ ${ }^{2}$ Laboratoire de Biologie et Environment marine, Université de La Rochelle, Pôle Science Av. Michel Crépeau, \\ 17042 La Rochelle, France
}

\begin{abstract}
To assess the in situ impact of oysters Crassostrea gigas on planktonic protist and bacteria communities and the potential contribution of protozoa to their food resource intake, the abundance and the diversity of protists and bacteria were followed in 2 Atlantic coastal ponds, with and without oysters. The protist biomass in such ponds was high, with a maximum in spring of $982 \mu \mathrm{g} \mathrm{C}$ $\mathrm{l}^{-1}$ and a minimum in winter of $179 \mu \mathrm{g} \mathrm{Cl}^{-1}$. Whatever the season, the presence of oysters $\left(20 \mathrm{~m}^{-2} \mathrm{cor}-\right.$ responding to an average of $23 \mathrm{mg}$ dry weight $\mathrm{m}^{-2}$ ) induced a significant decrease in $>5 \mu \mathrm{m}$ protist abundance. On the contrary, planktonic organisms $<5 \mu \mathrm{m}$, such as Chlorophyta flagellates and bacteria, developed similarly in both ponds. It can be assumed that such depletion in micro-sized protists was especially related to the grazing activity of $C$. gigas, which efficiently retains $>5 \mu \mathrm{m}$ particles. In spring, oyster grazing triggered dramatic changes in the protist community by lowering the taxonomic diversity. In autumn and winter, the presence of oysters deeply influenced the taxonomic structure of the protist communities: $>5 \mu \mathrm{m}$ protists could only develop in the control pond, whereas they were removed by filtration in the oyster pond; on the contrary, $<5 \mu \mathrm{m}$ protists that were not retained were favoured in the oyster pond. The results showed that hetero/mixotrophic protists represent an important potential resource in coastal ponds: flagellates $>5 \mu \mathrm{m}$ were the main protist resource for $C$. gigas; ciliates represented the second resource, with a substantial contribution in autumn; diatoms and dinoflagellates, though efficiently removed, represented a weak carbon resource. Our study supports the hypothesis that oysters may access the strong bacterioplanktonic production through hetero/mixotrophic protists, which would thus allow the transfer of carbon from the microbial loop towards C. gigas.
\end{abstract}

KEY WORDS: Bivalve $\cdot$ Oysters $\cdot$ Food source $\cdot$ Coastal pond $\cdot$ Microbial food web $\cdot$ Protists $\cdot$ Bacteria . Trophic link

Resale or republication not permitted without written consent of the publisher

\section{INTRODUCTION}

Charente-Maritime, along the French Atlantic coast, is the most important oyster farming area in Europe: shellfish cultures extend over lower parts of tidal flats (4800 ha) where oysters are grown from larvae to adult size. They are also located in land-based oyster ponds (3000 ha, mainly in the Marennes-Oléron area) traditionally

*E-mail: cdupuy@ifremer.fr used for fattening and greening marke oysters on vian tables (Korringa 1976). Tidal flats and coastal ponds are 2 hydrodynamically contrasting systems. Broad muddy bays suffer high and variable levels of turbidity due to the influence of tidal currents and wind-induced resuspension. Seasonal and spatial variations of seston quantity and quality, together with their effects on bivalve nutrition, have been studied on numerous occasions in the Marennes-Oléron Bay (Héral et al. 1987, Zurburg et al. 1994, Pastoureaud et al. 1996, Hawkins et al. 1998). 
In contrast, ponds are earth basins with a clay bottom, and renewal of seawater occurs for a few days at each spring tide. Once a pond has been filled with new coastal water, which is loaded with silt, nutrients and coastal planktonic assemblages, it functions like a closed system during the subsequent neap-tide period: silt settles, so that shallow waters become clear again and phytoplanktonic and/or microphytobenthic species can develop. Fattening of oysters has been achieved through feeding on rich phytoplankton and resuspended microphytobenthic communities, as previously reported by studies mainly focused on the phytoplanktonic growth potential in ponds (Robert et al. 1979, Robert 1983, Zanette 1980, Chrétiennot-Dinet \& Guillocheau 1987, Turpin et al. 1999) and bacterial biomass and production (Delmas et al. 1992). However, in semiclosed systems, such as ponds, where nutrients are quickly exhausted, phytoplankton and phytobenthos cannot entirely satisfy the energy requirements of oysters (Héral 1985). Bacterioplankton accounts for between 17 and $50 \%$ of the planktonic organic carbon biomass in coastal ponds (Frikha et al. 1987, Delmas et al. 1992), but oysters cannot feed on such picocells, which are not retained by their gills (Barillé et al. 1993). Besides phytoplanktonic diatoms (Fiala-Médioni et al. 1983), phytoflagellates (Barillé et al. 1993) and toxic dinoflagellates (Bardouil et al. 1996), oysters retain in vitro cultured ciliates (Le Gall et al. 1997) or a natural ciliate and flagellate planktonic community (Dupuy et al. 1999); accordingly, protozoa may transfer carbon and probably nitrogen from the microbial food web towards upper trophic levels.

This grazing activity may deeply influence the abundance and composition of water-column microbiota (Kemp et al. 1990, Riemann et al. 1990, Baker et al. 1998). Oysters obtain energy resources by filtering suspended particles from seawater and their growth depends upon the nutritive value of the retained seston (Berg \& Newell 1986) and the trophic capacity of coastal waters (Héral 1985). Oysters use a wide variety of living cells as well as protists (e.g. phytoplankton, protozoa) and detritus (Riera \& Richard 1996). One of the main feeding processes that can be involved in this impact is the differential particulate uptake dependent on their size (Vahl 1972, Riisgård 1988, Stenton-Dozey \& Brown 1992) and their quality (Shumway et al. 1985, Newell et al. 1989).

The current study investigated the in situ influence of Crassostrea gigas (Thunberg) grazing on the diversity and abundance of water-column protists (diatoms, dinoflagellates, flagellates and ciliates) in Atlantic coastal ponds. Our aim was to assess the in situ impact of oysters on planktonic microbiota, together with a possible contribution of protozoa in food resource intake by oysters, in order to control the occurrence of a realistic trophic link between bacterioplankton production, protozoa and the benthic suspension feeder C. gigas.

Our experimental design monitored the weekly changes in bacteria and protist community abundances during 3 water sequestration cycles, in spring, autumn and winter. This study compared the changes in a pond with oysters, at a density used by farmers, to those in a pond with no oysters.

\section{MATERIALS AND METHODS}

Experimental procedure. The study was performed in 2 experimental coastal ponds, in the oyster rearing area 'Marais du Plomb' (L'Houmeau, near La Rochelle, French Atlantic coast). Both ponds were dug in clay sediments 15 yr ago and their flat bottoms are composed of thin layers of silt resulting from sedimentation of marine particles brought by turbid coastal waters and destabilisation of surrounding terrestrial banks. The 2 experimental coastal ponds, dug at the same time, are located side by side and have the same limited surface area $\left(200 \mathrm{~m}^{2}\right)$ and depth $(\sim 1 \mathrm{~m})$. Owing to the closeness of these 2 ponds, they have undergone the same climatic conditions with similar temperature and salinity of water and wind regimes.

To estimate the impact of oysters on protist and bacteria planktonic communities, the temporal changes in planktonic assemblages were monitored in spring, autumn and winter during 3 sequestration cycles by sampling water weakly in a pond with oysters (oyster pond) and comparing the samples to those from a pond with no oysters (control pond). A mean density of 20 oysters $\mathrm{m}^{-2}$ was used and corresponded to a density used by farmers for fattening and greening oysters (Goulletquer \& Héral 1997). At the beginning of the experiments, oysters were put together in plastic nettings ( $1 \mathrm{~m}$ length, $0.5 \mathrm{~m}$ wide, mesh size averaged $1 \mathrm{~cm})$, which were placed on iron tables at $0.5 \mathrm{~m}$ off the bottom of the pond at low tide. Then, both ponds were supplied with coastal water, via channels, at high spring tides. Two days after the arrival of the seawater in the ponds, turbidity levels were low and the first sampling was made. It was monitored by 4 weekly samplings. Seawater was sequestrated in the ponds for 3 to $4 \mathrm{wk}$, which resulted in regular modifications of ecological conditions in these semi-closed systems. At the end of the sequestration period, the ponds were emptied at ebb tide and filled again with new seawater during the next high tide.

Preliminary tests were performed for defining an accurate sampling strategy of the pond water column in order to estimate average values of both seston parameters and abundances of microbiota over the 
whole surface of each pond; each pond was divided into 12 squares ( $3 \mathrm{~m}$ wide) and 1 sub-surface water sample was taken in each square at each sampling date. These 12 samples were collected with a 2.51 'Van Doorn' bottle (Wildco) and $500 \mathrm{ml}$ from each sample was mixed in a single opaque carboy, taken rapidly to the laboratory and treated. The final $6 \mathrm{l}$ sample was assumed to represent a spatial average estimate of water column parameters within each pond and for each sampling date.

Pigment determination. To perform fluorimeter and HPLC analyses, triplicate seawater samples (from 30 to $150 \mathrm{ml}$ ) extracted from the previous 61 sample were filtered in a $10 \mathrm{~mm} \mathrm{Hg}$ vacuum onto a $2.5 \mathrm{~cm}$ GF/F filter, which was kept at $-80^{\circ} \mathrm{C}$ in Corning glass tubes until extraction. For fluorimeter analyses, filters were put into $7 \mathrm{ml}$ of $99 \%$ methanol and stored for $1 \mathrm{~h}$ in the dark at $4{ }^{\circ} \mathrm{C}$. Concentrations of extracted chlorophyll a (chl a) and pheopigment were measured using a Turner fluorimeter No. 10037 , equipped with a Corning CS 5-60 filter for excitation light and a Corning CS 2-64 filter for emitted light. Pigment amounts were calculated according to Neveux \& Lantoine (1993). For HPLC analyses of chlorophylls and carotenoids, pigments were extracted from filters in $2 \mathrm{ml}$ of $100 \%$ methanol by crushing and stirring with a glass rod, and were then placed in a bath sonicator for $30 \mathrm{~s}$. Vials were then stored for $1 \mathrm{~h}$ in the dark at $4^{\circ} \mathrm{C}$. The extract was passed through a Whatman GF/F glass-fiber filter and diluted just before injection with ammonium acetate buffer $(0.5 \mathrm{M})$ to $80 \%$ methanol. Pigments were analysed by HPLC according to Wright et al. (1991). The system consisted of a Kontron liquid chromatograph equipped with 3 HPLC 422 pump, a diode array detector 440 and a spectrofluorometer SFM 25. The reverse phase column used was Allsphere ODS2, $25 \mathrm{~cm} \times 4.6 \mathrm{~mm}$ inner diameter, $5 \mu \mathrm{m}$ particle size (Alltech). Pigments were identified by diode array spectroscopy during elution and quantified by injection of standard pigments.

Measurements of total particulate matter (TPM). TPM was measured according to Aminot \& Chaussepied (1983). The previous 61 sample was mixed and triplicate subsamples (from 300 to $1000 \mathrm{ml}$ ) were filtered within $1 \mathrm{~h}$ onto a Whatman GF/C $(47 \mathrm{~mm}$ in diameter) under a vacuum pressure $<10 \mathrm{~mm} \mathrm{Hg}$. Filters were previously combusted at $490^{\circ} \mathrm{C}$ for $2 \mathrm{~h}$ to eliminate their subsequent organic carbon content and then weighed. After sample filtration, each filter was rinsed twice with ammonium formiate (OSI, $68 \mathrm{~g} \mathrm{l}^{-1}$ ) to remove salt, dried at $60^{\circ} \mathrm{C}$ for $12 \mathrm{~h}$ and weighed to measure TPM. To determine the proportion of particulate inorganic matter (PIM) versus particulate organic matter (POM), filters were combusted at $490^{\circ} \mathrm{C}$ for $2 \mathrm{~h}$ and then weighed. Knowing that the particulate organic carbon (POC) made up half of the POM, we were able to estimate the POC in the water for the 3 periods and calculate the proportion of protist biomass in the 3 cycles of water sequestration in the pond.

Enumeration of bacteria. Triplicate samples $(10 \mathrm{ml})$ were fixed with $0.2 \mu \mathrm{m}$ filtered formaldehyde (final concentration $1 \%$ ). A subsample was stained according to Porter \& Feig (1980) with DAPI (final concentration $2.5 \mu \mathrm{g} \mathrm{ml}{ }^{-1}$ ) for $15 \mathrm{~min}$ at $5^{\circ} \mathrm{C}$ in the dark, filtered onto a black Nuclepore filter $(0.2 \mu \mathrm{m}$ pore size) and examined under UV excitation with an epifluorescence microscope (Leitz Dialux 22 EB) to enumerate heterotrophic bacteria.

Taxonomy and enumeration of microphytoplankton community. An aliquot of pond water was fixed with formaldehyde (final concentration 1\%) and stained with alkaline Lugol's solution. Microphytoplanktonic cells were enumerated in Utermöhl settling chambers (Hydro-Bios combined plate chambers) under a reverse microscope. Diatoms were identified up to the genus, and the sizes of all cells (length and width) were measured through a calibrated ocular micrometer. From cell size measurements, the mean cell volume of each taxon was calculated by equating the shape to standard geometric configurations. The cell volume was converted into carbon units using a theoretical

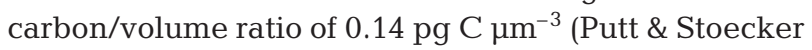
1989).

Autotrophic and hetero/mixotrophic protist community: taxonomy and enumeration. Flagellates, dinoflagellates and ciliates were fixed, stained and enumerated according to the methods used by Haas (1982), Caron (1983) and Sherr et al. (1994), modified by Dupuy et al. (1999). Cells were enumerated in Utermöhl settling chambers (Hydro-Bios combined plate chambers) using a reverse epifluorescence microscope (Zeiss Axiovert, $100 \mathrm{~W}$ mercury lamp and blue light excitation). Dinoflagellates and ciliates were identified up to the genus. Dinoflagellates are heterotrophic or autotrophic cells; we considered this group as mixotrophic cells. Ciliates were considered as heterotrophic cells. The method of flagellate enumeration excluded the taxonomic determination of flagellates due to the presence of a black Nuclepore filter. Only the size and the cell outlines of flagellates were estimated. Moreover, the method used in this study permitted us to distinguish autotrophic from heterotrophic flagellates via repeated interchange of the filter sets (Caron 1983); phototrophic cells (crimson under UV 365 nm excitation and red colored under green 450 to $490 \mathrm{~nm}$ excitation) and heterotrophic cells (blue under UV excitation and invisible under green excitation) were separately enumerated. However, it was not possible to differentiate autotrophic cells and mixotrophic cells. In fact, 
flagellates were characterized according to their shape, size and mode of acquiring food. Each flagellate which had a different size or shape or which had a different mode of acquiring food was regarded as a new group.

From replicate cell size measurements of all autotrophic and hetero/mixotrophic protists, the mean cell volume of each group was calculated by equating the shape to standard geometric configurations. The cell volume was converted into carbon units, using a theo-

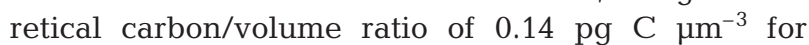
flagellates and $0.17 \mathrm{pg} \mathrm{C} \mathrm{m}^{-3}$ for dinoflagellates and ciliates (Putt \& Stoecker 1989, corrected for glutaraldehyde fixative, according to Leakey et al. 1994).

Diversity and structure of protist communities. To assess the impact of oysters on the diversity and abundance of planktonic protists, rank species abundance curves were used. This method has been widely used in marine ecology (Pielou 1975, Frontier 1985, Warwick \& Clarke 1994). Warwick (1986) proposed the use of the ABC method (abundance/biomass comparison) for describing changes in macrozoobenthic communities in response to disturbance or pollution. However, when applied to tidal flat assemblages (Beukema 1988) or estuarine polluted communities (Dauer et al. 1993), application of the $\mathrm{ABC}$ method may result in unacceptable misclassifications of the disturbance status of a given benthic assemblage. According to Warwick \& Clarke (1994), the ABC method should be used with caution for organisms other than macrobenthos, but remains efficient in detecting changes in a rank of species within polychaetes, which are known to be a good indicator of pollution. An alternative solution, in the case of a planktonic community with a short life span and small-sized species, is to use rank-frequency diagrams (RFD) as proposed by Frontier (1985). RFDs are similar to 'simple dominance curves' (see Clarke 1990), but are based on the log-log plot of ranked abundances, expressed as percentages of the total abundance of all species in the sample, against the relevant species rank. As indicated by Frontier (1985) from zooplanktonic and phytoplanktonic studies, changes in the shape of RFDs characterize temporal changes in community structure: an S-shaped curve indicates the predominance of 1 or 2 species in a low species richness assemblage (stage 1, pioneer community). An increase of the species richness may induce a more even distribution of abundance between species and, thus, the curve becomes more convex (stage 2, mature community). At the end of the ecological succession (stage 3), first ranked species are more dominant and the curve becomes more linear; the species richness is also lower than in the previous stage. In some cases, e.g. a recolonization phase after a disturbance or after an intense nutrient input, a few species can quickly develop and the RFD appears irregular and coarsely rectilinear (stage 1' intermediate between stages 1 and 2; see Frontier 1985 for details). In our study, RFDs were carried out on the total abundances of planktonic protists, excluding bacteria (size $<1 \mu \mathrm{m}$ ), which are not protists and are not retained by oyster gills.

Estimation of protist carbon removal by oysters and contribution of various protists to the carbon resource removed by oysters. To estimate the living protist carbon removed from each type of protist (diatoms, ciliates, etc.) by Crassostrea gigas filtration, the field carbon biomass of each type of protist in the control pond (see above for calculation) was multiplied by the corresponding oyster clearance rate, defined as the theoretical water volume entirely cleared from particles per time unit (Bayne \& Widdows 1978) and related to the total oyster biomass in the pond $\left(20\right.$ oysters $\left.\mathrm{m}^{-2}\right)$. The clearance rate $\left(\mathrm{l} \mathrm{h}^{-1} \mathrm{~g}^{-1}\right)$, standardized per $\mathrm{g}$ of oyster dry weight according to Riisgård (1988), was taken from Deslous-Paoli et al. (1987) for diatoms and Euglenophyceae, from Dupuy et al. (1999) for ciliates, dinoflagellates and $>5 \mu \mathrm{m}$ flagellates and from Barillé et al. (1993) for $<5 \mu \mathrm{m}$ flagellates. The contribution of each type of protist to oyster food was expressed as a percentage of the total protist resource.

Statistical treatment. A 2-way partially nested ANOVA was used to estimate differences in water column variables and protist and bacteria abundances due to seasons and treatments (Sokal \& Rohlf 1981). Both seasons and treatments represent fixed factors, with 3 levels (spring, autumn and winter) and 2 levels (oyster pond vs control pond), respectively. Dates of observation ( 5 dates per season) are hierarchical to the season factor and are assumed to be a random factor, whose mean squares will be used for testing effects of seasons, treatments and their interaction. This is a mixed-model ANOVA (Sokal \& Rohlf 1981). Since there were no replicates of experimental units within each sampling date, i.e. treatment ponds and/or 12point spatial survey within a pond, triplicate measurements made within a sampling date only represent the variation within hydrological samples with the error term which was used for testing the level of variation between sampling dates within seasons.

The logarithmic transformation $\left(\log _{10}\right)$ was used in the case of microbiota abundance because it is assumed that increase of microbial population size during a given time is proportional to its abundance (multiplicative effect). Tests for homogeneity of variances (Bartlett's test) of untransformed and $\log _{10}$ transformed data were performed and results confirmed this assumption, except in the case of dinoflagellates and flagellates (size $<5 \mu \mathrm{m}$ ), whose abundances were extremely high during blooms that occurred on 9 and 22 June, respectively. According to Underwood (1981), 
when data are not normally distributed, as observed in these 2 groups, Bartlett's test is too conservative and could cause rejection of the assumption of homoscedasticity, due to lack of normality.

The a posteriori SNK procedure (Student-NewmanKeuls test) was used for testing differences in means between treatments and seasons (Underwood 1981).

\section{RESULTS}

\section{Biotic groups and proportions of auto/mixotrophic and $>5$ and $<5 \mu \mathrm{m}$ heterotrophic nanoflagellates}

Large autotrophic cells were mostly diatoms, and large hetero/mixotrophic cells were mainly dinoflagellates and ciliates. Small auto/mixotrophic and heterotrophic cells were represented by nanoflagellates (between 3 and $19 \mu \mathrm{m})$. The percentage of $>5$ and $<5 \mu \mathrm{m}$ auto/mixotrophic nanoflagellates (ANF) was always higher compared to the percentage of $>5$ and $<5 \mu$ m heterotrophic nanoflagellates (HNF) (Table 1). Picoplankton exclusively comprised heterotrophic bacteria.

\section{Sources of variation in seston, protist and bacteria temporal changes}

There were always significant differences in dateto-date variability within seasons and treatment whatever the variables (Table 2). There was no evidence of a significant difference in POM between oyster and control ponds. However, significantly higher POM values in spring (in both oyster and control ponds) and autumn (control pond), as indicated by the SNK test, accounted for a season $\times$ pond interaction (figure and results not shown). Seasonal changes in chl $a$ were similar in both oyster and control ponds, despite higher values of chl $a$ in the control pond in spring ( $p<0.001$ for the season $\times$ pond interaction). However, chl $b$ pigments significantly varied with season, but were higher in the oyster pond during the spring than in the control pond (SNK test, significant season $\times$ pond interaction, Table 2 ).

The presence of oysters significantly reduced the abundance of diatoms which were assessed by determining the presence of fucoxanthin, dinoflagellates, ciliates and $>5 \mu \mathrm{m}$ flagellates $(\mathrm{p}<0.001$, Table 2$)$, but there was no evidence of any oyster impact on the abundance of both $<5 \mu \mathrm{m}$ flagellates and bacteria ( $\mathrm{p}>$ $0.05)$ whatever the season. Significant interactions between seasons and ponds were mainly due to higher values of a given biotic group within a season. For instance (1) diatom abundances were lower in winter in both controls than in other seasons and oyster ponds
Table 1. Percentage of $>5$ and $<5 \mu \mathrm{m}$ auto/mixotrophic nanoflagellates (ANF) and heterotrophic nanoflagellates $(\mathrm{HNF})$ in the control pond in spring, autumn and winter

\begin{tabular}{|c|c|c|c|c|}
\hline Season & \multicolumn{2}{|c|}{$\begin{array}{l}>5 \mu \mathrm{m} \text { flagellates } \\
\% \text { ANF } \% \text { HNF }\end{array}$} & \multicolumn{2}{|c|}{$<5 \mu \mathrm{m}$ flagellates } \\
\hline Spring & 69.2 & 31 & 89.6 & 10.4 \\
\hline Autumn & 98.9 & 1.1 & 97 & 3 \\
\hline Winter & 94.1 & 5.9 & 99.7 & 0.3 \\
\hline
\end{tabular}

(see Fig. 3A, SNK test); (2) a significantly higher abundance of dinoflagellates occurred in the control pond only during the spring and autumn (see Figs. 1B \& 2B, SNK test); and (3) abundances of $>5 \mu \mathrm{m}$ flagellates were 10 times higher in the control pond in spring than in the other ponds whatever the season.

\section{Comparative temporal changes of bacteria and protist abundances in ponds with and without oysters}

Temporal changes in abundance of the main protists and bacteria were followed and compared in 2 coastal ponds with and without oysters, located side by side, during 3 sequestration cycles.

\section{Spring cycle (May-June)}

Two days after the water sequestration (first sampling date, 27 May), diatom, $>5 \mu \mathrm{m}$ flagellate, dinoflagellate and ciliate abundances were already much lower in the oyster pond than in the control pond (Fig. 1A to D), whereas bacteria and $<5 \mu \mathrm{m}$ flagellate abundances were similar in both ponds (Fig. $1 \mathrm{E}, \mathrm{F}$ ). Bacteria were highly abundant (ca $5 \times 10^{9}$ cells l$^{-1}$ ). A bloom of diatoms soon developed in the control pond during the first and third week (500 and $630 \times$ $10^{4}$ diatoms $\mathrm{l}^{-1}$ ), which was never observed in the oyster pond (ca $7 \times 10^{4}$ diatoms $1^{-1}$ ). Similarly, dinoflagellates were dominant in the control pond $(87 \times$ $10^{4}$ dinoflagellates $\mathrm{l}^{-1}$ ) and even when they decreased after the third week, they still remained much more abundant in the control pond $\left(16.4 \times 10^{4}\right.$ dinoflagellates $\left.\mathrm{l}^{-1}\right)$ than in the oyster pond $\left(0.01 \times 10^{4}\right.$ dinoflagellates $\mathrm{l}^{-1}$ ). In the third week, large $>5 \mu \mathrm{m}$ flagellates only developed in the control pond (ca $70 \times 10^{6} \mathrm{cells}^{-1}$ ). At the end of the cycle, a bloom of ciliates grew in the control pond (ca $15 \times 10^{4}$ ciliates $\mathrm{l}^{-1}$ ), simultaneously with a strong decrease in diatoms and dinoflagellates. The presence of oysters strongly lowered the abundance of diatoms, $>5 \mu \mathrm{m}$ flagellates, dinoflagellates and ciliates (Tables $2 \& 3$, Fig. $1 \mathrm{~A}$ to $\mathrm{D}_{\text {; }}$ са $0.4 \times 10^{4}$ 
Table 2. Results from 2-way partially nested ANOVA on seasonal changes in water column parameters and microbiota abundances

\begin{tabular}{|c|c|c|c|c|c|}
\hline Variable & Source of variation & df & MS & $F$-ratio & $\mathrm{p}$ \\
\hline \multirow[t]{5}{*}{ Chlorophyll a } & Seasons & 2 & 100.584 & 1.54 & 0.254 \\
\hline & Ponds & 1 & 5.791 & 0.6 & 0.440 \\
\hline & Seasons $\times$ ponds & 2 & 142.688 & 14.85 & $<0.001$ \\
\hline & Date (seasons) & 12 & 65.248 & 6.79 & $<0.001$ \\
\hline & Error & 72 & 9.609 & & \\
\hline \multirow[t]{5}{*}{ Chlorophyll $b$} & Seasons & 2 & 7.997 & 5.28 & 0.023 \\
\hline & Ponds & 1 & 12.3773 & 55.74 & $<0.001$ \\
\hline & Seasons $\times$ ponds & 2 & 8.3994 & 37.82 & $<0.001$ \\
\hline & Date (seasons) & 12 & 1.5136 & 6.82 & $<0.001$ \\
\hline & Error & 72 & 0.2221 & & \\
\hline Alloxanthin & Seasons & 2 & 11.6899 & 1.32 & 0.304 \\
\hline \multirow[t]{4}{*}{ (Cryptophyceae) } & Ponds & 1 & 5.3573 & 11.41 & 0.001 \\
\hline & Seasons $\times$ ponds & 2 & 6.9577 & 14.81 & $<0.001$ \\
\hline & Date (seasons) & 12 & 8.8821 & 18.91 & $<0.001$ \\
\hline & Error & 72 & 0.4697 & & \\
\hline \multirow{5}{*}{$\begin{array}{l}\text { Fucoxanthin } \\
\text { (diatoms) }\end{array}$} & Seasons & 2 & 4.7397 & 6.38 & 0.013 \\
\hline & Ponds & 1 & 5.3217 & 45.81 & $<0.001$ \\
\hline & Seasons $\times$ ponds & 2 & 1.8844 & 16.22 & $<0.001$ \\
\hline & Date (seasons) & 12 & 0.7431 & 6.4 & $<0.001$ \\
\hline & Error & 72 & 0.1162 & & \\
\hline \multirow[t]{5}{*}{ Dinoflagellates } & Seasons & 2 & 7.4144 & 3.55 & 0.061 \\
\hline & Ponds & 1 & 39.5745 & 171.73 & $<0.001$ \\
\hline & Seasons $\times$ ponds & 2 & 15.9127 & 69.05 & $<0.001$ \\
\hline & Date (seasons) & 12 & 2.0857 & 9.05 & $<0.001$ \\
\hline & Error & 72 & 0.2305 & & \\
\hline \multirow[t]{5}{*}{ Ciliates } & Seasons & 2 & 3.2868 & 1.08 & 0.372 \\
\hline & Ponds & 1 & 5.2998 & 23.85 & $<0.001$ \\
\hline & Seasons $\times$ ponds & 2 & 0.4066 & 1.83 & 0.168 \\
\hline & Date (seasons) & 12 & 3.0546 & 13.75 & $<0.001$ \\
\hline & Error & 72 & 0.2222 & & \\
\hline \multirow[t]{5}{*}{$>5 \mu \mathrm{m}$ flagellates } & Seasons & 2 & 0.387 & 0.07 & 0.936 \\
\hline & Ponds & 1 & 47.728 & 29.1 & $<0.001$ \\
\hline & Seasons $\times$ ponds & 2 & 19.913 & 12.14 & $<0.001$ \\
\hline & Date (seasons) & 12 & 5.873 & 3.58 & $<0.001$ \\
\hline & Error & 72 & 1.64 & & \\
\hline \multirow{5}{*}{$<5 \mu \mathrm{m}$ flagellates } & Seasons & 2 & 7.7438 & 3.22 & 0.076 \\
\hline & Ponds & 1 & 1.0176 & 3.11 & 0.082 \\
\hline & Seasons $\times$ ponds & 2 & 2.9091 & 8.88 & $<0.001$ \\
\hline & Date (seasons) & 12 & 2.4056 & 7.34 & $<0.001$ \\
\hline & Error & 72 & 0.3276 & & \\
\hline
\end{tabular}

diatoms $\mathrm{l}^{-1}, 0$ dinoflagellates $\mathrm{l}^{-1}, 0.9 \times 10^{4}$ ciliates $\mathrm{l}^{-1}$ and $4.7 \times 10^{6}>5 \mu \mathrm{m}$ flagellates), whereas it increased the development of bacteria and small flagellates (Tables $2 \& 3$, Fig. 1E; $3690 \times 10^{6}$ flagellates $\mathrm{l}^{-1}$ in the oyster pond vs $90 \times 10^{6}<5 \mu \mathrm{m}$ flagellates $\mathrm{l}^{-1}$ in the control pond).

HPLC analyses of pigments revealed the dominance of chl $b$ and lutein in the oyster pond throughout the cycle; this pigmentary signature, characteristic of Chlorophyta, was confirmed by the microscopic observation of a small Chlorophyta flagellate (ca $3 \mu \mathrm{m}$ ), which developed strongly in the oyster pond (Table 3, Fig. 1E).

To summarize, the abundance of large planktonic protist cells was always higher in the control pond, though it fluctuated during the cycle: diatoms mainly developed during the first and third week, dinoflagellates and $>5 \mu \mathrm{m}$ flagellates during the second week and ciliates at the end of the cycle. Only $<5 \mu \mathrm{m}$ auto/mixotrophic flagellates (Chlorophyta) and bacteria developed more intensely in the oyster pond (Table 3).

\section{Autumn cycle (September-October)}

Within $2 \mathrm{~d}$ of water sequestration (first sampling date, 23 September), abundance of diatoms, dinoflagellates, ciliates and flagellates were already much lower in the oyster pond than in the control pond (i.e. 0.3 vs $5 \times 10^{4}$ dinoflagellates $\mathrm{l}^{-1}, 1.8$ vs $8 \times 10^{4}$ ciliates $\mathrm{l}^{-1}$ and 5 vs $15 \times 10^{6}$ flagellates $\mathrm{l}^{-1}$ ). Only bacteria were 
A

Diatoms $\left(\times 10^{4}\right.$ cells $\left.^{-1}\right)$

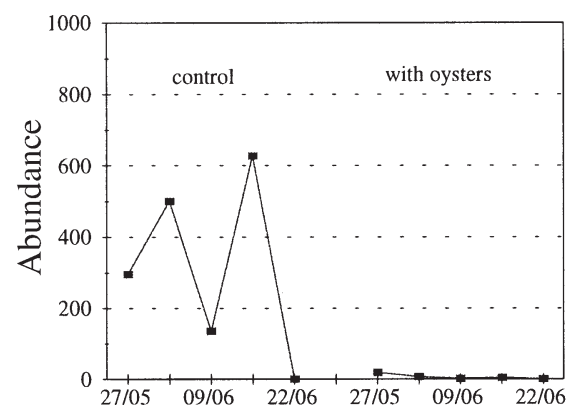

$\mathrm{D}$

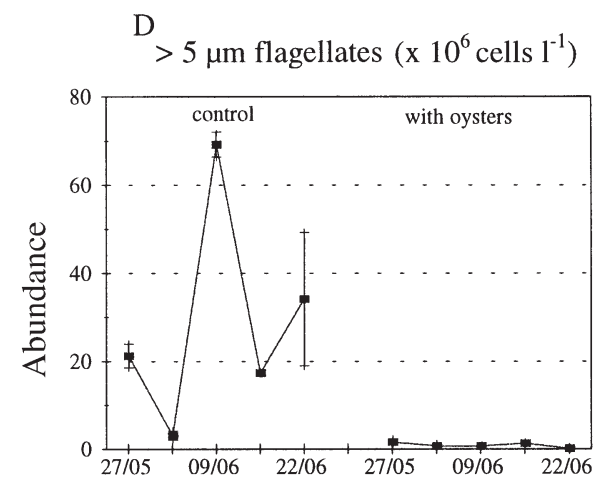

B Dinoflagellates ( $\times 10^{3}$ cells $\left.{ }^{-1}\right)$

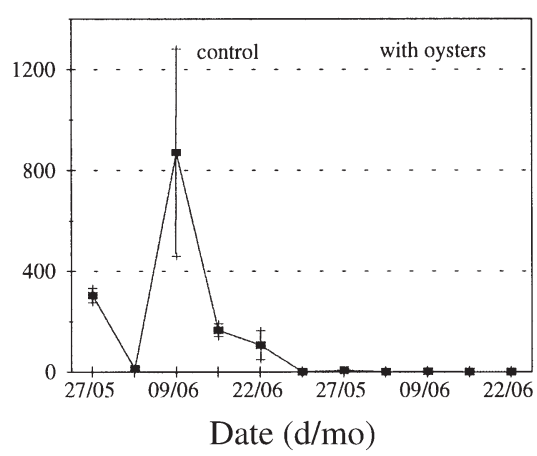

$\mathrm{E}$ $<5 \mu$ m flagellates $\left(\times 10^{6}\right.$ cells $\left.~^{-1}\right)$

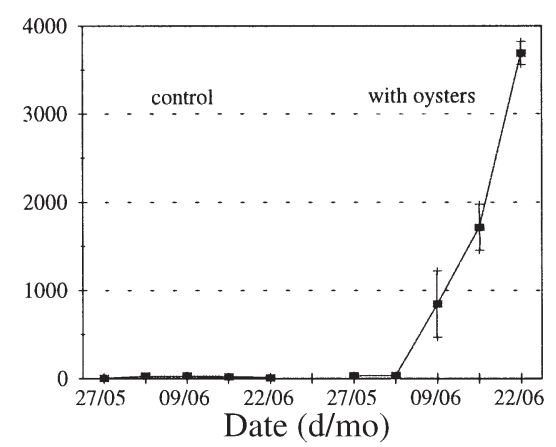

C Ciliates $\left(\times 10^{4}\right.$ cells $\left.1^{-1}\right)$

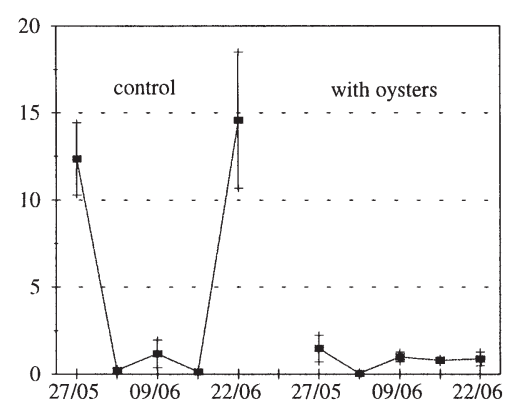

F Bacteria $\left(\times 10^{9}\right.$ cells $\left.^{-1}\right)$

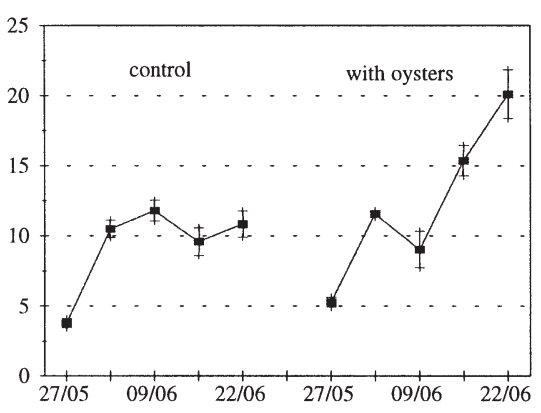

Fig. 1. Abundances of planktonic protists and bacteria in both the control and oyster ponds during the spring. Abundance data (mean $\pm \mathrm{SD}, \mathrm{n}=3$, except for diatoms) were collected from 3 subsamples

similarly abundant in the 2 ponds (ca $4 \times 10^{7}$ cells l$^{-1}$ ). During the second week of the cycle, small flagellates increased in both ponds (Fig. 2E). Conversely, most protists developed only in the control pond: diatoms in the third week $\left(20 \times 10^{4}\right.$ cells $\left.^{-1}\right)$, and dinoflagellates and large flagellates at the end of the cycle $\left(6 \times 10^{6}\right.$ large flagellates $1^{-1}$ and $15 \times 10^{4}$ dinoflagellates $\mathrm{1}^{-1}$ ). Ciliate abundance soon dropped in both ponds and thereafter fluctuated weakly. Bacterial abundance evolved at a similar rate in both ponds (with or without oysters) throughout the cycle (Table 3).
HPLC analyses of pigments revealed higher fucoxanthin values during the second and third week, confirming that diatoms only developed in the control pond. Alloxanthin (specific to Cryptophyceae) became dominant in the control pond in the last week, simultaneously with the large flagellate bloom and an increase in chl $a$, which solely developed in this pond (Fig. 2). Conversely, chl $b$ (specific to Chlorophyta) was higher in the oyster pond during the first $3 \mathrm{wk}$.

To summarize, most protists dominated in the control pond: diatoms developed during the third week, and

Table 3. Mean cell abundances of protists and bacteria in the both control and oyster ponds in spring, autumn and winter

\begin{tabular}{|c|c|c|c|c|c|c|}
\hline & \multicolumn{2}{|c|}{ Spring } & \multicolumn{2}{|c|}{ Autumn } & \multicolumn{2}{|c|}{ Winter } \\
\hline & Control pond & Oyster pond & Control pond & Oyster pond & Control pond & Oyster pond \\
\hline Diatoms $\left(\times 10^{4}\right)$ & 312 & 6 & 8 & 5 & 1 & 4 \\
\hline Ciliates $\left(\times 10^{3}\right)$ & 57 & 8 & 24 & 9 & 4 & 3 \\
\hline Dinoflagellates $\left(\times 10^{4}\right)$ & 29.1 & 0.1 & 5.8 & 0.5 & 0.2 & 0.1 \\
\hline$>5 \mu \mathrm{m}$ flagellates $\left(\times 10^{5}\right)$ & 290 & 10 & 21 & 4 & 22 & 5 \\
\hline$<5 \mu \mathrm{m}$ flagellates $\left(\times 10^{6}\right)$ & 15 & 1260 & 13 & 8 & 4 & 3 \\
\hline Bacteria $\left(\times 10^{8}\right)$ & 93 & 123 & 55 & 61 & 22 & 14 \\
\hline
\end{tabular}


A

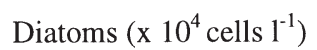

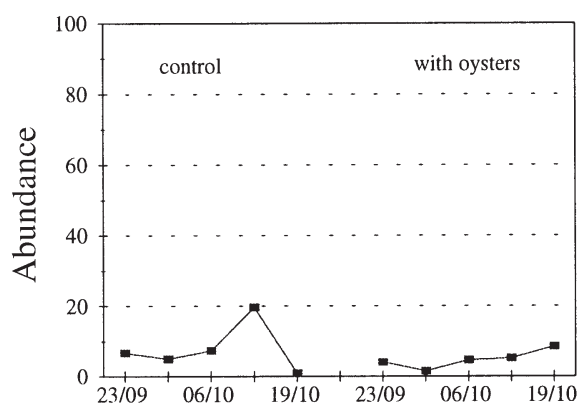

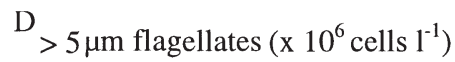

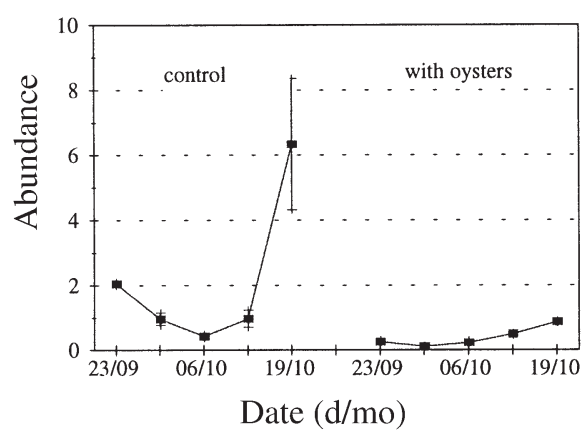

B Dinoflagellates ( $10^{3}$ cells $^{-1}$ )

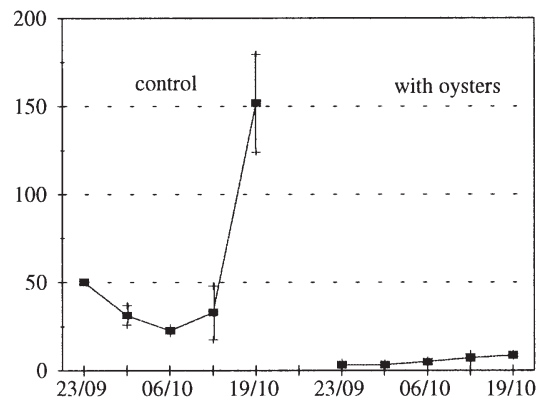

$\mathrm{E}$

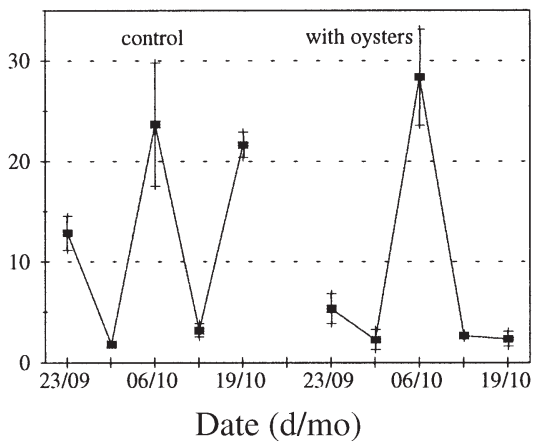

C

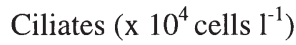

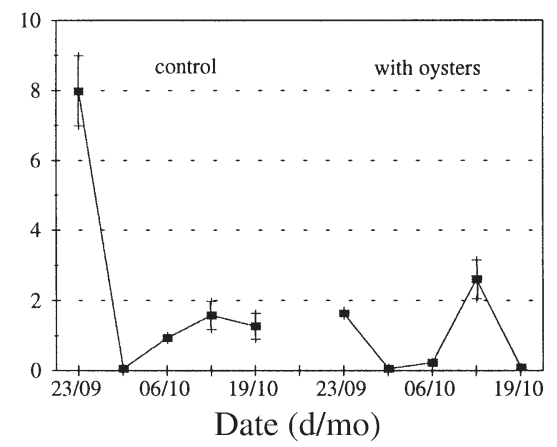

Fig. 2. Abundances of planktonic protists in both control and in oyster ponds during the autumn. Abundance data (mean $\pm \mathrm{SD}, \mathrm{n}=3$, except for diatoms) were collected from 3 subsamples
$>5 \mu \mathrm{m}$ Cryptophyceae flagellates and dinoflagellates in the last week. Though there was no development of ciliates in any pond during this cycle, their abundance was lower in the oyster pond. Small $<5 \mu$ flagellates increased similarly in both ponds during the second week. Among them, Chlorophyta were dominant in the oyster pond. Bacterial abundance evolved similarly in both ponds (Table 3).

\section{Winter cycle (November-December)}

Protist abundance was much lower in the ponds during the winter cycle than in spring (Figs. 1 \& 3): 6 versus $600 \times 10^{4}$ diatoms $\mathrm{l}^{-1}, 0.7$ versus $87 \times 10^{4}$ dinoflagellates $\mathrm{l}^{-1}, 0.9$ versus $15 \times 10^{4}$ ciliates $\mathrm{l}^{-1}$ and 4 versus $3600 \times 10^{6}$ small flagellates $\mathrm{l}^{-1}$. Only large $>5 \mu \mathrm{m}$ flagellates developed at a similar abundance between winter and autumn $\left(8.7\right.$ vs $6 \times 10^{6}$ flagellates $\mathrm{l}^{-1}$ ). During the winter cycle, several protist communities fluctuated in both ponds (Fig. 3): dinoflagellates weakly developed in the second week in the control pond and in the third week in the oyster pond. Conversely, > $4 \mathrm{~m}$ flagellates strongly developed at the end of the cycle in the control pond $\left(9 \times 10^{6}\right.$ cells $\mathrm{l}^{-1}$, Table 3). The number of dinoflagellates was higher in the oyster pond in the third week. The ciliate community fluctuated in both ponds, though their abundance was higher in the control pond than in the oyster pond at the end of sequestration cycle.

HPLC analyses of pigments revealed higher chl a and alloxanthin values (specific to Cryptophyceae) starting in the second week in the control pond, confirming that the $>5 \mu \mathrm{m}$ flagellate bloom which developed in the control pond was triggered by Cryptophyceae flagellates.

To summarize, most protists were poorly represented in both ponds during the winter cycle and only $>5 \mu \mathrm{m}$ Cryptophyceae flagellates developed in the control pond at the end of the cycle (Table 3).

\section{Impact of oysters on the diversity and structure of the planktonic protist community}

RFDs for protists were performed in both ponds on each of the 5 sampling dates within the 3 seasons.

\section{Spring cycle (May-June)}

Two days after complete water renewal, the structure of the protist assemblage was identical in both the oyster and control ponds (Fig. 4 spring, Table 4). High diversity (37 groups) and similar convex RFDs characterized both systems. However, during the course of 

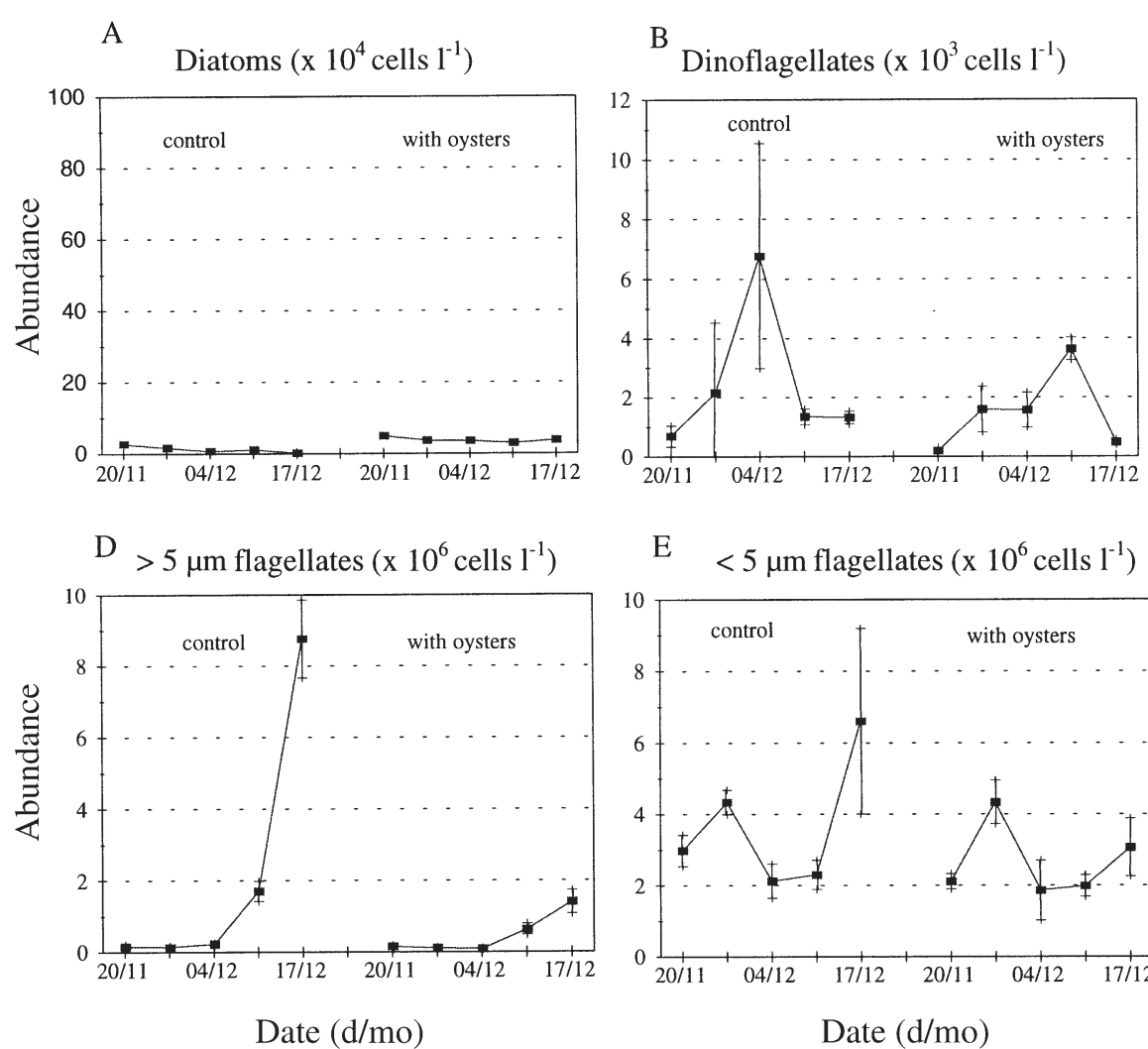

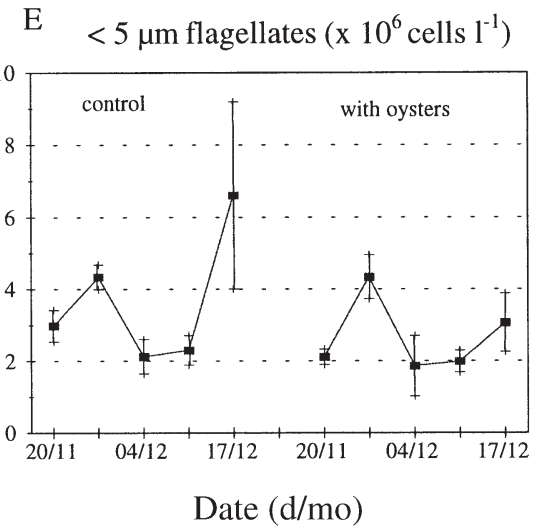

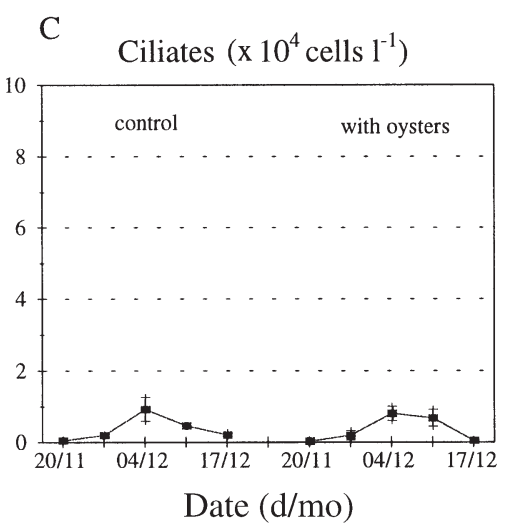

Fig. 3. Abundances of planktonic protists in both control and oyster ponds during the winter. Abundance data (mean $\pm \mathrm{SD}, \mathrm{n}=3$, except for diatoms) were collected from 3 subsamples the sampling period, temporal changes in the structure of the protist assemblages differed significantly.

On the one hand, in the control pond, the number of groups quickly decreased, but remained nearly constant (between 21 and 26, Table 4) during the following $4 \mathrm{wk}$. Thus, the structure of the protist assemblage was simplified and slightly dominated by $>5 \mu \mathrm{m}$ ANF and/or HNF (Table 4). The dominant group at the beginning of the sampling period, in the first and third weeks, was a $>5 \mu \mathrm{m}$ ANF and the next most dominant was a diatom, Cylindrotheca sp. In the second and fourth weeks, the dominant group was a $>5 \mu \mathrm{m} \mathrm{HNF}$ (Table 4) and the next most dominant a > $5 \mu \mathrm{m}$ ANF.

On the other hand, in the oyster pond, groups sharply decreased in number and reached only 11 in the last week (Table 4). Two groups were dominant at the beginning, a $>5 \mu \mathrm{m}$ ANF (58\%) and a $>5 \mu \mathrm{m} \mathrm{HNF}$ $(28 \%) .<5 \mu \mathrm{m}$ ANF dominated the other protists during the last 3 wk (more than $99 \%$ of total abundance). Consequently, RFDs were typical of a pioneer planktonic assemblage (stage 1), which characterized the spring bloom (Fig. 1E). It should be noted that this structural analysis is consistent with an ANOVA performed on $<5 \mu \mathrm{m}$ flagellates (Table 2): there was significantly higher abundance of $<5 \mu \mathrm{m}$ flagellates in the oyster pond in spring (SNK test and Fig. 1E) than in the control pond or in other seasons, accounting for the highly significant season $\times$ pond interaction (Table 2) together with the non-significant effect of both season and pond factors $(p=0.076$ and 0.082 , respectively, Table 4).

\section{Autumn cycle (September-October)}

In the control pond, temporal changes in the protist assemblage structure were characterized by shifts in the dominance between a $<5 \mu \mathrm{m}$ ANF and $>5 \mu \mathrm{m}$ Cryptophyceae. At the beginning of the autumnal cycle, a $<5 \mu \mathrm{m}$ ANF dominated (67\%) and was followed by a $>5 \mu \mathrm{m}$ Cryptophyceae $(18 \%)$. During the second and third weeks, $>5 \mu \mathrm{m}$ Cryptophyceae flagellates became the most abundant protists (70 and $39 \%$ respectively) before being replaced by $<5 \mu \mathrm{m}$ autotrophic flagellates during the last week ( $61 \%$ of total abundance, Table 4). RFDs remained similar in shape with an even proportion of species (stage 2). Diversity of biotic groups decreased from 37 to 27 during the whole sampling period, but remained higher than spring diversity.

In the oyster pond, the structure of protist asssemblages significantly changed during each season. A 

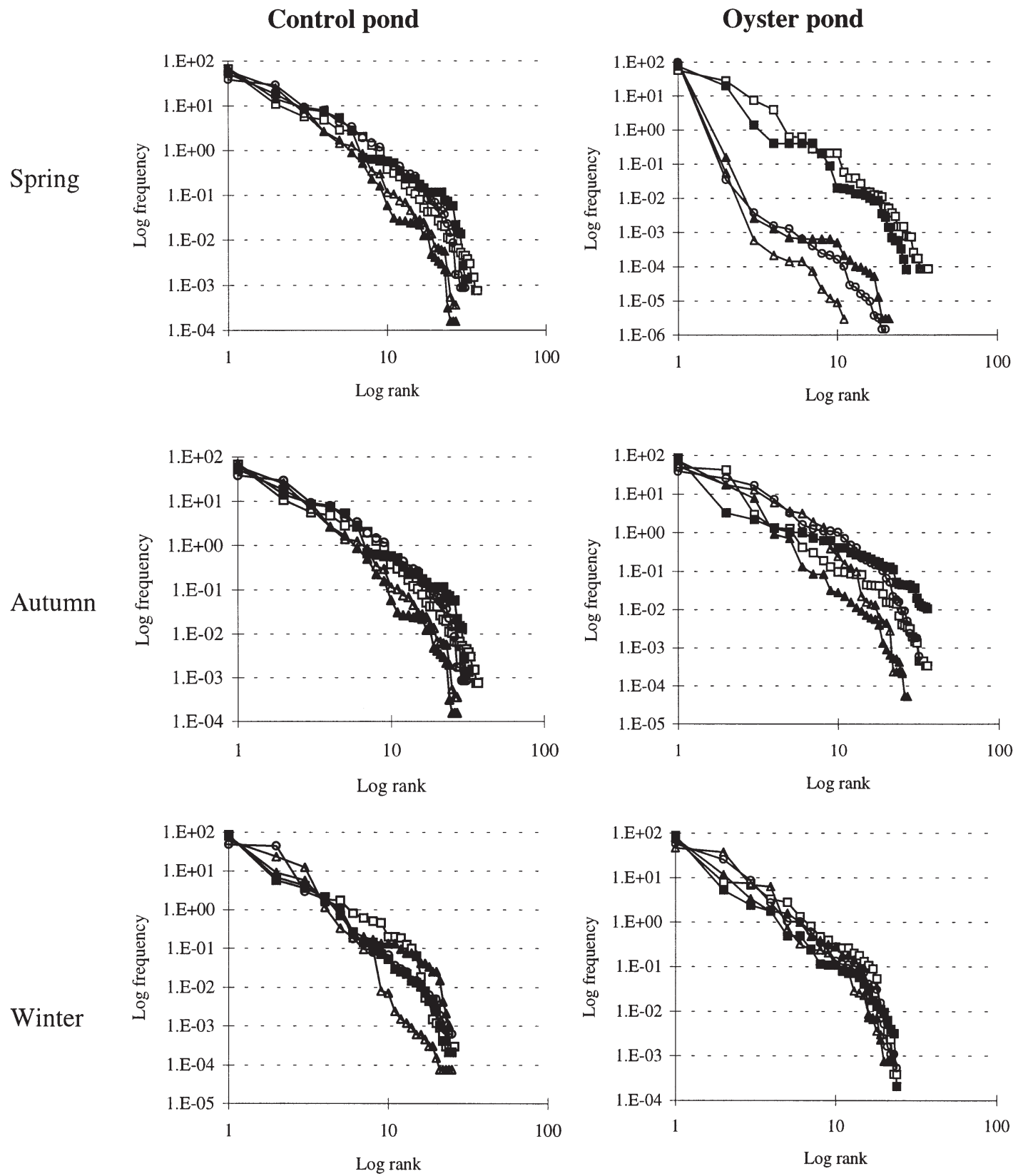

$\longrightarrow$ - second day after supply $\longrightarrow$-first week $-\mathbf{\Delta}-$ second week $-\mathbf{O}-$ third week $-\Delta-$ fourth week

Fig. 4. Rank-frequency diagrams in spring, autumn and winter during each sequestration cycle in the control pond (left panels) and the oyster pond (right panels)

bloom of $<5 \mu \mathrm{m}$ ANF (86\% of total abundance) occurred during the first week (Fig. 2E, Table 4). RFDs evolved from convex at the beginning to slighty concave during the first week, then turned convex from the second week onwards. At the beginning of the sampling period, the number of groups was similar in both ponds, but it increased in the oyster pond during the first week (44 vs 32, Table 4). The initial dominant taxon was a diatom (Chaetoceros sp., ca $50 \%$ ), but a $<5 \mu \mathrm{m}$ ANF from the group Chlorophyta soon dominated until the end of the sampling period (Table 4). The second dominant group was a $<5 \mu \mathrm{m}$ ANF at the beginning and in the first week, with 42 and $3 \%$ of total abundance, respectively. From the second week onwards, Cryptophyceae flagellates were the second dominant group (17 to $25 \%$ of total abundance), 
Table 4. Number of groups (Nt) and frequency (\%) of (A) the dominant group and (B) the second dominant group during the 3 seasons in both the control and oyster ponds. ANF = auto/mixotrophic nanoflagellate; HNF $=$ heterotrophic nanoflagellate

\begin{tabular}{|c|c|c|c|c|c|c|c|}
\hline Season & $\begin{array}{l}\text { Date } \\
(\mathrm{d} / \mathrm{mo})\end{array}$ & $\mathrm{Nt}$ & $\begin{array}{l}\text { Control pond - } \\
\text { Dominant } \\
\text { group }\end{array}$ & $\begin{array}{c}\text { Frequency } \\
(\%)\end{array}$ & $\mathrm{Nt}$ & $\begin{array}{l}\text { Oyster pond } \\
\text { Dominant } \\
\text { group }\end{array}$ & $\begin{array}{c}\text { Frequency } \\
(\%)\end{array}$ \\
\hline \multicolumn{8}{|c|}{ (A) Dominant group } \\
\hline \multirow[t]{5}{*}{ Spring } & $27 / 05$ & 37 & $>5 \mu \mathrm{m}$ ANF & 44 & 37 & $>5 \mu \mathrm{m}$ ANF & 58 \\
\hline & $02 / 06$ & 23 & $>5 \mu \mathrm{m}$ ANF & 55 & 27 & $>5 \mu \mathrm{m}$ ANF & 77 \\
\hline & 09/06 & 21 & $>5 \mu \mathrm{m} \mathrm{HNF}$ & 46 & 21 & $<5 \mu \mathrm{m}$ ANF & 99.8 \\
\hline & $15 / 06$ & 26 & $>5 \mu \mathrm{m}$ ANF & 37 & 20 & $<5 \mu \mathrm{m}$ ANF & 99.9 \\
\hline & $22 / 06$ & 22 & $>5 \mu \mathrm{m} \mathrm{HNF}$ & 60 & 11 & $<5 \mu \mathrm{m}$ ANF & 99.9 \\
\hline \multirow[t]{5}{*}{ Autumn } & $23 / 09$ & 37 & $<5 \mu \mathrm{m}$ ANF & 67 & 36 & Chaetoceros sp. & 50 \\
\hline & $29 / 09$ & 32 & $<5 \mu \mathrm{m}$ ANF & 53 & 44 & $<5 \mu \mathrm{m}$ ANF & 86 \\
\hline & $06 / 10$ & 27 & Cryptophyceae & 70 & 27 & $<5 \mu \mathrm{m}$ ANF & 73 \\
\hline & $12 / 10$ & 31 & Cryptophyceae & 39 & 32 & $<5 \mu \mathrm{m}$ ANF & 39 \\
\hline & $19 / 10$ & 27 & $<5 \mu \mathrm{m}$ ANF & 61 & 25 & $<5 \mu \mathrm{m}$ ANF & 52 \\
\hline \multirow[t]{5}{*}{ Winter } & $20 / 11$ & 26 & $<5 \mu \mathrm{m}$ ANF & 82 & 24 & $<5 \mu \mathrm{m}$ ANF & 74 \\
\hline & $27 / 11$ & 25 & $<5 \mu \mathrm{m}$ ANF & 87 & 24 & $<5 \mu \mathrm{m}$ ANF & 89 \\
\hline & $04 / 12$ & 24 & $<5 \mu \mathrm{m}$ ANF & 81 & 23 & $<5 \mu \mathrm{m}$ ANF & 78 \\
\hline & $10 / 12$ & 25 & Cryptophyceae & 48 & 24 & $<5 \mu \mathrm{m}$ ANF & 59 \\
\hline & $17 / 12$ & 25 & Cryptophyceae & 62 & 19 & $<5 \mu \mathrm{m}$ ANF & 47 \\
\hline \multicolumn{8}{|c|}{ (B) Second dominant group } \\
\hline \multirow[t]{5}{*}{ Spring } & $27 / 05$ & 37 & Cylindrotheca sp. & 10 & 37 & $>5 \mu \mathrm{m} \mathrm{HNF}$ & 28 \\
\hline & $02 / 06$ & 23 & Cylindrotheca sp. & 15 & 27 & $>5 \mu \mathrm{m} \mathrm{HNF}$ & 20 \\
\hline & $09 / 06$ & 21 & $>5 \mu \mathrm{m}$ ANF & 22 & 21 & $<5 \mu \mathrm{m}$ ANF & 0.2 \\
\hline & $15 / 06$ & 26 & Cylindrotheca sp. & 15 & 20 & $<5 \mu \mathrm{m}$ ANF & 0.03 \\
\hline & $22 / 06$ & 22 & $>5 \mu \mathrm{m}$ ANF & 15 & 11 & $<5 \mu \mathrm{m}$ ANF & 0.05 \\
\hline \multirow[t]{5}{*}{ Autumn } & $23 / 09$ & 37 & $<5 \mu \mathrm{m}$ ANF & 11 & 36 & $<5 \mu \mathrm{m}$ ANF & 42 \\
\hline & $29 / 09$ & 32 & Cryptophyceae & 18 & 44 & $<5 \mu \mathrm{m}$ ANF & 3 \\
\hline & $06 / 10$ & 27 & $<5 \mu \mathrm{m}$ ANF & 14 & 27 & Cryptophyceae & 17 \\
\hline & $12 / 10$ & 31 & $<5 \mu \mathrm{m}$ ANF & 29 & 32 & Cryptophyceae & 25 \\
\hline & $19 / 10$ & 27 & Cryptophyceae & 25 & 25 & Cryptophyceae & 17 \\
\hline \multirow[t]{5}{*}{ Winter } & $20 / 11$ & 26 & Cryptophyceae & 7 & 24 & $<5 \mu \mathrm{m}$ ANF & 8 \\
\hline & $27 / 11$ & 25 & $<5 \mu \mathrm{m}$ ANF & 6 & 24 & $<5 \mu \mathrm{m}$ ANF & 5 \\
\hline & $04 / 12$ & 24 & Cryptophyceae & 9 & 23 & $<5 \mu \mathrm{m}$ ANF & 12 \\
\hline & $10 / 12$ & 25 & $<5 \mu \mathrm{m}$ ANF & 45 & 24 & Cryptophyceae & 26 \\
\hline & $17 / 12$ & 25 & $<5 \mu \mathrm{m}$ ANF & 24 & 19 & Cryptophyceae & 38 \\
\hline
\end{tabular}

although they were dominant in the control pond (Table 4).

\section{Winter cycle (November-December)}

In the control pond, RFDs were concave at the beginning and, during the first $2 \mathrm{wk}$, displayed the dominance of 1 group (abundance higher than 80\%). During the last $2 \mathrm{wk}$, RFDs turned convex, showing a more even distribution of proportions among the top 4 first groups out of the 25 groups which constituted the winter protist assemblage (Table 4). The initial number of groups was lower in winter, ca 25, than in spring and autumn, but remained constant during the whole sampling period. $\mathrm{A}<5 \mu \mathrm{m}$ ANF was dominant during the first week; from the third week onwards, a Cryptophyceae flagellate dominated (48 and $62 \%$ at the end of the sampling period).
In the oyster pond, RFDs showed similar profiles as in the control pond (Fig. 4). At the beginning of the sampling period, the number of groups was close to that in the control pond, ca 24, but it decreased at the end of the period, ca 19 (Table 4). The dominant taxon during the whole cycle was a $<5 \mu \mathrm{m}$ ANF. From the third week onwards, the second dominant taxon was a Cryptophyceae flagellate (26 and $38 \%$, for the third and fourth week, respectively); this taxon developed well in the control pond but was never the first dominant group in the oyster pond (Table 4).

\section{DISCUSSION}

The aim of this study was to assess (1) the in situ impact of Crassostrea gigas on planktonic bacteria and protists in Atlantic coastal ponds and (2) the relative contribution of autotrophic, heterotrophic and mixo- 
trophic protists to oyster food resource intake. Such interaction would support the potential role of protozoa as a realistic trophic link between the high bacterioplankton production in coastal ponds and benthic suspension feeding bivalves.

\section{Impact of oysters on protist and bacteria communities}

Two complementary technical approaches were simultaneously used to assess the abundance and taxonomic identification of the protist community: (1) microscopic enumeration and observation and (2) HPLC analysis of pigment signature.

Pond protists and bacteria ranged in size from 1 to $250 \mu \mathrm{m}$, and were mainly represented by large autotrophic diatoms (5 to $230 \mu \mathrm{m}$ ); large hetero/ mixotrophic dinoflagellates (8 to $70 \mu \mathrm{m}$ ) and ciliates (8 to $250 \mu \mathrm{m})$; small auto/mixotrophic nanoflagellates (3 $\mathrm{mm})$ and hetero/mixotrophic microflagellates (>5 to $19 \mu \mathrm{m})$. Picoplankton exclusively comprised bacteria (1 $\mu \mathrm{m})$.

After isolating the pond for $2 \mathrm{~d}$, and during the whole cycle, significant changes in the abundance of large $>5 \mu \mathrm{m}$ flagellates, diatoms, dinoflagellates and ciliates were weaker in the oyster pond than in the control pond for each season sampled. Even though protist abundance was much lower in winter than in spring and autumn, the large Cryptophyceae flagellate, which bloomed at the end of December in the control pond, was unable to reach the same level of development in the presence of oysters. It can be assumed that such a general depletion in micro-sized protists was related to the grazing activity of Crassostrea gigas. Cryptophytes are known to be frequently consumed by bivalves (Shumway et al. 1985, Loret 1999). However, other species such as micro-mesozooplanktonic cells (bivalve and crustacean larvae, copepods) can be fed by the protist community: in the control pond, protists were food for these species. In contrast, in the oyster pond, oysters fed on larvae species (Dupuy et al. 2000), and only copepods, which are not retained by oysters due to their large size, were directly in competition with oysters. However, given the density of oysters $\left(20\right.$ oysters $\mathrm{m}^{-2}$ ) and copepods (up to $1000 \mathrm{l}^{-1}$, Crottereau pers. comm.), protist depletion was mainly due to the predation of oysters.

However, planktonic protists $<5 \mu \mathrm{m}$, such as Chlorophyta flagellates and bacteria, developed at a similar or more intense rate in the oyster pond, as if they were either not grazed or even favoured by the presence of oysters. In May-June, the strong development of $<5 \mu \mathrm{m}$ Chlorophyta flagellates in the oyster pond (Fig. 1) resulted from the inability of Crassostrea gigas to retain them efficiently. The absence of Chlorophyta at the same time in the control pond can probably be explained by the fact that, here, this tiny flagellate was actively consumed by hetero/mixotrophic protists, which developed abundantly in the absence of oysters and perhaps due to the presence of micro-mesozooplankton. Conversely, in the oyster pond, as the oysters grazed on protists, the small flagellate could develop without any predation pressure. Moreover, the oysters' excretory products or nutrient release related to active grazing might have stimulated the development of bacteria and small autotrophic flagellates. Such hypotheses have been evoked to explain the dominance of a photosynthetic picoeukaryote, Ostreococcus tauri (Courties et al. 1994, Chrétiennot-Dinet et al. 1995) in the marine Mediterranean Thau lagoon, where intensive oyster culturing has developed.

The current evidence of a depletion in large $>5 \mu \mathrm{m}$ protists in the presence of oysters reflects in situ a substantial capacity of Crassostrea gigas to select among particles by size. These results are in concordance with the retention spectrum of oysters already examined in previous experimental studies (Deslous-Paoli et al. 1987, Barillé et al. 1993).

Previous laboratory studies showed that oysters retained in vitro cultured ciliates or field protists like flagellates and ciliates (Le Gall et al. 1997, Dupuy et al. 1999). Moreover, we report here the first in situ proof of a significant retention of a protist community by oysters.

RFDs have been used to investigate the effect of oyster grazing on protist communities. Considering that oysters are the dominant predators in the oyster pond, oyster grazing thus triggers dramatic changes in coastal pond protist communities by lowering the taxonomic diversity in spring. The most striking difference between protist planktonic communities in ponds with or without oysters lies in the respective dominant taxon: in autumn and in winter, $>5 \mu \mathrm{m}$ flagellates (pigmentary signature of Cryptophyceae) strongly developed in the control pond at the end of the experimental period, although a $<5 \mu \mathrm{m}$ flagellate was dominant in the oyster pond. Because oysters have a retention preference for $>5 \mu \mathrm{m}$ protists, their presence strongly influences the taxonomic structure of the pond protist communities.

\section{Estimation of protist carbon removal by oysters and contribution of each various protist to the carbon resource removed by oysters}

The calculation of the quantity of carbon removal by oysters based on the multiplication of the organism biomass in the control pond, the oyster biomass, and clearance rates for each organism can only be an 
approximate estimation. Indeed, the presence of oysters in a coastal pond can modify the functioning of the planktonic food web, especially on concentration of dissolved organic matter (Sornin et al. 1990). Moreover, the predation of micro-mesozooplankton (copepods, bivalve and crustacean larvae, etc.) on protists in the control pond has not been taken into account. However, few data on estimation of protist carbon removal by oysters, so this calculation allows us to obtain a first approximation of the use of trophic resources in the oyster pond. This use of organisms varies quantitatively and qualitatively throughout the year. As oysters retain organic particles according to their cell size and their field abundance, the removal of protist carbon from the pond depends upon (1) the importance of the protist resource in the water column, (2) the oyster retention efficiency of the available protists, and (3) the importance of the oyster population grazing in the pond. The biomass of protist carbon varied in the control pond according to season (Table 4): it was maximal in spring $\left(982 \mu \mathrm{g} \mathrm{C} \mathrm{l}^{-1}\right)$, decreased about 4 -fold in autumn and was minimal in winter $\left(179 \mu \mathrm{g} \mathrm{C} \mathrm{l}^{-1}\right)$. Subsequently, oysters removed quantitatively much more protist carbon (Table 5) in spring $\left(110 \mathrm{mg} \mathrm{C} \mathrm{m}^{-2} \mathrm{~h}^{-1}\right)$ than in autumn $(30 \mathrm{mg}$ $\mathrm{C} \mathrm{m}^{-2} \mathrm{~h}^{-1}$ ) or winter $\left(12.5 \mathrm{mg} \mathrm{C} \mathrm{m}^{-2} \mathrm{~h}^{-1}\right)$. Moreover, this energy resource was qualitatively different throughout the year; in spring, $>5 \mu \mathrm{m}$ flagellates were the first energy resource and represented $74 \%$ of the carbon removed by oysters (Fig. 5), whereas diatoms, dinoflagellates and ciliates only contributed 11, 6 and $5 \%$ respectively (Fig. 5). In autumn, diatoms represented the most important part of particulate carbon removed by oysters $(57 \%$; Table 5$)$; ciliates and $>5 \mu \mathrm{m}$ flagellates were the second resource (16\%) (Fig. 5). In winter, the poor protist community resulted in weak oyster removal, and bloom-forming Cryptophyceae flagellates were the only subsequent protist resource at this period $(88 \%)$. Ciliates, diatoms and $<5 \mu \mathrm{m}$ flagellates represented a weak protist carbon resource removed by oysters, 6,2 and $3 \%$ respectively (Fig. 5). These data indicate a somewhat minor role for $<5 \mu \mathrm{m}$ flagellates, whereas $>5 \mu \mathrm{m}$ flagellates are likely to be the primary protist food resource for Crassostrea gigas. This is therefore the first time that the importance of flagellates has been proven in this type of environment where diatoms used to be considered the main resource. Ciliates and diatoms represent the second most important resource and make a substantial contribution in autumn. Dinoflagellates are removed efficienctly but represent a weak carbon resource due to their small volume or exceptional abundance. However, other trophic resources exist, which have not been taken into account in this carbon removal. In this study, the contribution of carbon from non-protists may
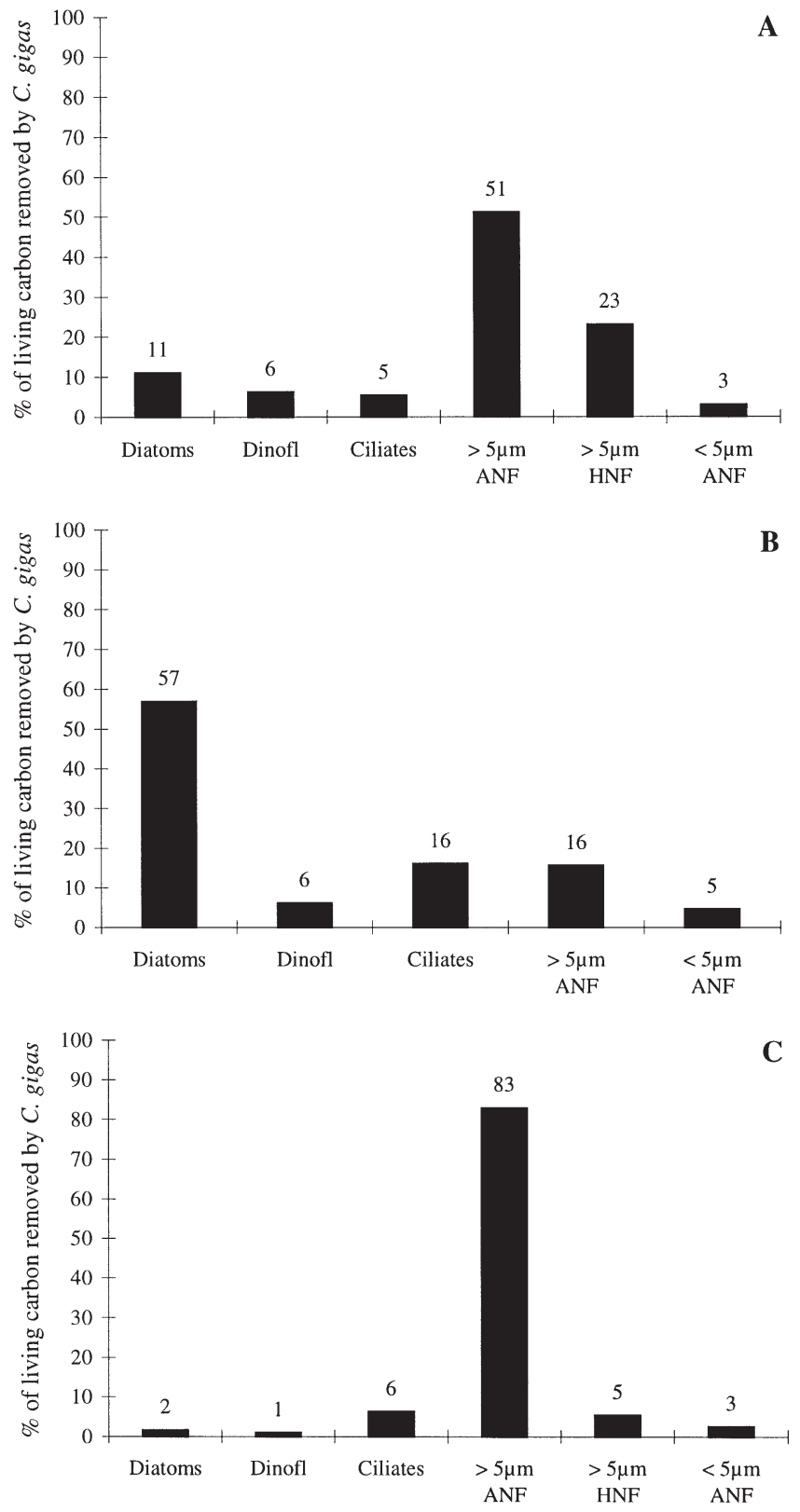

Fig. 5. Estimated percentages of living protist carbon removed by Crassostrea gigas filtration in (A) spring, (B) autumn and (C) winter. ANF = auto/mixotrophic nanoflagellates; $\mathrm{HNF}=$ heterotrophic nanoflagellates, Dinofl = dinoflagellates

be high depending on the season (Table 6: from 38 to $88 \%$ ). An analysis of POC has not been made, but it is known that the detritic matter in these environments, as well as in the Marennes-Oléron Bay $(84 \%$, FeuilletGirard et al. 1994), can reach very high levels, up to $67 \%$ of detritic matter (Crottereau 1999). Studies have shown that the oyster uses this organic matter as food and demonstrated opportunist trophic behavior in the Marennes-Oléron Bay (Riera \& Richard 1996). 
Table 5. Estimates of living microbial carbon removed by Crassostrea gigas filtration. Clearance rate from Dupuy et al. (1999) for ciliates, dinoflagellates and flagellates. Clearance rate from Deslous-Paoli et al. (1987) for diatoms and Euglenophyceae. Particle abundance from present data. Oyster biomass: $27 \mathrm{mg} \mathrm{m}^{-2}$ during the spring, $25 \mathrm{mg} \mathrm{m}^{-2}$ during the autumn and $17 \mathrm{mg} \mathrm{m}^{-2}$ during the winter. Carbon removed $(=$ carbon biomass of particles $\times$ clearance rate $\times$ oyster biomass). ANF $=$ auto/mixotrophic nanoflagellate; $\mathrm{HNF}=$ heterotrophic nanoflagellate

\begin{tabular}{|c|c|c|c|c|}
\hline & $\begin{array}{c}\text { Particle } \\
\text { biomass } \\
\left(\mathrm{mg} \mathrm{C} \mathrm{m}^{-2}\right)\end{array}$ & $\begin{array}{l}\text { Clearance } \\
\text { rate } \\
\left(1 \mathrm{~h}^{-1} \mathrm{~g}^{-1}\right)\end{array}$ & $\begin{array}{c}\text { Carbon } \\
\text { removed } \\
\left(\mathrm{mg} \mathrm{C} \mathrm{m}^{-2} \mathrm{~h}^{-1}\right)\end{array}$ & $\%$ of total \\
\hline \multicolumn{5}{|l|}{ Spring } \\
\hline Diatoms & 90 & 5 & 12 & 11 \\
\hline Ciliates & 32 & 6.8 & 6 & 5 \\
\hline Dinoflagellates & 63 & 4 & 7 & 6 \\
\hline$>5 \mu \mathrm{m}$ ANF & 520 & 4 & 56 & 51 \\
\hline$<5 \mu \mathrm{m}$ ANF & 38 & 3.2 & 3 & 3 \\
\hline$>5 \mu \mathrm{m} \mathrm{HNF}$ & 234 & 4 & 25 & 23 \\
\hline$<5 \mu \mathrm{m} \mathrm{HNF}$ & 4 & 3.2 & 0.3 & 0 \\
\hline Euglenophyceae & 0.3 & 5 & 0.04 & 0 \\
\hline Total & 982 & & 110 & \\
\hline \multicolumn{5}{|l|}{ Autumn } \\
\hline Diatoms & 134 & 5 & 16.8 & 57 \\
\hline Ciliates & 28 & 6.8 & 4.7 & 16 \\
\hline Dinoflagellates & 18 & 4 & 1.8 & 6 \\
\hline$>5 \mu \mathrm{m}$ ANF & 46 & 4 & 4.6 & 16 \\
\hline$<5 \mu \mathrm{m}$ ANF & 17 & 3.2 & 1.4 & 5 \\
\hline$>5 \mu \mathrm{m}$ HNF & 1 & 4 & 0.1 & 0.3 \\
\hline$<5 \mu \mathrm{m}$ HNF & 1 & 3.2 & 0.1 & 0.3 \\
\hline Euglenophyceae & 0 & 5 & 0.0 & 0.0 \\
\hline Total & 245 & & 30 & \\
\hline \multicolumn{5}{|l|}{ Winter } \\
\hline Diatoms & 2 & 5 & 0.21 & 2 \\
\hline Ciliates & 7 & 6.8 & 0.80 & 6 \\
\hline Dinoflagellates & 2 & 4 & 0.12 & 1 \\
\hline$>5 \mu \mathrm{m}$ ANF & 153 & 4 & 10.40 & 83 \\
\hline$<5 \mu \mathrm{m}$ ANF & 6 & 3.2 & 0.32 & 3 \\
\hline$>5 \mu \mathrm{m}$ HNF & 10 & 4 & 0.68 & 5 \\
\hline Euglenophyceae & 0.1 & 5 & 0.006 & 0.05 \\
\hline Total & 179 & & 12.5 & \\
\hline
\end{tabular}

on average, $93 \mathrm{l} \mathrm{m}^{-2} \mathrm{~h}^{-1}$ in a pond measuring $200 \mathrm{~m}^{3}$. This estimated population clearance rate could result in the removal of about $10 \%$ of the planktonic particles in the water volume $\left(200 \mathrm{~m}^{3}\right.$ ) within $1 \mathrm{~h}$. In spring, the abundance and diversity of the protist community strongly decreased in the oyster pond, which supported the conclusion that, during this period, grazing of 20 oysters $\mathrm{m}^{-2}$ may exceed the protist production for large taxon which are efficiently retained. Conversely, in autumn and winter, particle removal matched the trophic capacity of the pond in terms of protists.

Most studies on the importance of protists as a trophic link between the microbial food web and metazoa have focused on pelagic consumers as zooplankters (Berk et al. 1977, Porter et al. 1979, Jonsson \& Tiselius 1990, Gifford \& Dagg 1991, Hartmann et al. 1993, Sime-Ngando et al. 1995) or oyster larvae (Klaveness 1992, Baldwin \& Newell 1995). Only a few recent reports have been dedicated to benthic macroconsumers (Kreeger \& Newell 1996, Le Gall et al. 1997, Dupuy et al. 1999). These results support the hypothesis that hetero/mixotroph protists represent an important potential resource, directly accessible to the filter-feeding oyster which retains them. Indeed, in this study, the dinoflagellates can be mixotrophic species or even heterotrophic cells, and the flagellates, whatever

Table 6. Percentage of protist carbon compared to total POC for the 3 seasons

\begin{tabular}{|lccc|}
\hline Season & $\begin{array}{c}\text { POC } \\
\left(\mu \mathrm{g}^{-1}\right)\end{array}$ & $\begin{array}{c}\text { Protist biomass } \\
\left(\mu \mathrm{C}^{-1}\right)\end{array}$ & $\begin{array}{c}\text { \% of protist carbon/ } \\
\text { total POC }\end{array}$ \\
\hline Spring & 1596 & 982 & 62 \\
Autumn & 2103 & 245 & 12 \\
Winter & 801 & 179 & 22 \\
\hline
\end{tabular}

We can estimate the local impact of Crassostrea gigas filtration on the water column protist from the clearance rate and the oyster density in the pond. Taking into account the mean biomass used by oyster farmers in rearing ponds $\left(20\right.$ oysters $\mathrm{m}^{-2}$ ) and based on the mean clearance rates (Deslous-Paoli et al. 1987, Dupuy et al. 1999), the oyster population could filter, their size, are considered to be autotrophic cells (Table 1), but which cannot however be differentiated from mixotrophic cells (Granéli et al. 1999). Moreover, it must be noted that a flagellate considered to be autotrophic cells and which contains chloroplasts can feed equally well on bacteria (Havskum \& Riemann 1996) or other prey (Jones et al. 1995), and that in certain cases, the mortality rate of bacteria is essentially due to the grazing of pigmented flagellates (Havskum \& Riemann 1996). Taking into account that the available diatom production in ponds does not balance its energy schedule, Crassostrea gigas may have access to strong bacterioplanktonic production through hetero/mixotrophic protists, which would thus allow the transfer of carbon from the microbial loop towards the upper trophic levels. 
Acknowledgements. We gratefully acknowledge M. Bréret for technical assistance, C. Trichet for bacterial enumeration, C. Vérity for HPLC analyses, H. Hartmann for his help in field sampling, C. Bacher for assistance with statistics and S. Le Gall for critical review of the manuscript. This study was carried out with financial support from the Conseil Général de Charente-Maritime.

\section{LITERATURE CITED}

Aminot A, Chaussepied M (1983) Manuel des analyses chimiques en milieu marin. CNEXO, Brest

Baker SM, Levington JS, Kurdziel JP, Shumway SE (1998) Selective feeding and biodeposition by zebra mussels and their relation to changes in phytoplankton composition and seston load. J Shellfish Res 17:1207-1213

Baldwin BS, Newell RIE (1995) Relative importance of different size food particles in the natural diet of oyster larvae (Crassostrea virginica). Mar Ecol Prog Ser 120:135-145

Bardouil M, Bohec M, Bougrier S, Lassus P, Truquet P (1996) Feeding responses of Crassostrea gigas (Thunberg) to inclusion of different proportions of toxic dinoflagellates in their diet. Oceanol Acta 19:177-182

Barillé L, Prou J, Héral M, Bougrier S (1993) No influence of food quality, but ration-dependent retention efficiencies in the Japanese oyster Crassostrea gigas. J Exp Mar Biol Ecol 171:91-106

Bayne BL, Widdows J (1978) The physiological ecology of two populations of Mytilus edulis L. Oecologia 37:137-162

Berg JA, Newell RIE (1986) Temporal and spatial variations in the composition of seston available to the suspension feeder Crassostrea virginica. Estuar Coast Shelf Sci 23: 375-386

Berk SG, Brownlee DC, Heinle DR, Kling HJ, Colwell RR (1977) Ciliates as a food source for marine planktonic copepods. Microb Ecol 4:27-40

Beukema JJ (1988) An evaluation of the ABC-method (abundance/biomass comparison) as applied to macrozoobenthic communities living on tidal flats in the Dutch Wadden Sea. Mar Biol 99:425-433

Caron DA (1983) Technique for enumeration of heterotrophic and phototrophic nanoplankton, using epifluorescence microscopy, and comparison with other procedures. Appl Environ Microbiol 46:491-498

Chrétiennot-Dinet MJ, Guillocheau N (1987) Etude de diatomées d'écosystèmes marins côtiers. Observations nouvelles en microscopie électronique. Cah Biol Mar 28: 271-279

Chrétiennot-Dinet MJ, Courties C, Vaquer A, Neveux J, Claustre H, Lautier J, Machado C (1995) A new marine picoeucaryote: Ostreococcus tauri gen. et sp. nov. (Chlorophyta, Prasinophyceae). Phycologia 34:285-292

Clarke KR (1990) Comparisons of dominance curves. J Exp Mar Biol Ecol 138:143-157

Courties C, Vaquer A, Lautier J, Troussellier M, ChrétiennotDinet MJ, Neveux J, Machado C, Claustre H (1994) Smallest eukaryotic organism. Nature 370:255

Crottereau C (1999) Dynamique des populations bactériennes dans un marais maritime atlantique: contribution des activités ectoproteolytique et d'uptake des acides aminés à la production bactérienne. Thèse d'Océanologie, Université d'Aix-Marseille II

Dauer DM, Luckenbach MW, Rodi AJ Jr (1993) Abundance biomass comparison (ABC method): effects of an estuarine gradient, anoxic/hypoxic events and contaminated sediments. Mar Biol 116:507-518
Delmas D, Frikha MG, Reymond H, Linley EAS, Collos Y (1992) Long term microbial community dynamics in a coastal marine pond. Mar Microb Food Webs 6:39-54

Deslous-Paoli JM, Héral M, Goulletquer P, Boromthanarat W, Razet D, Garnier J, Prou J, Barillé L (1987) Evolution saisonnière de la filtration de bivalves intertidaux dans des conditions naturelles. Oceanis 13:575-579

Dupuy C, Le Gall S, Hartmann HJ, Bréret M (1999) Retention of ciliates and flagellates by the oyster Crassostrea gigas in French Atlantic coastal ponds: protists as a trophic link between bacterioplankton and benthic suspension-feeders. Mar Ecol Prog Ser 177:165-175

Dupuy C, Vaquer A, Lam-Höai T, Rougier C, Mazouni N, Lautier, J, Collos Y, Le Gall S (2000) Feeding rate of the oyster Crassostrea gigas in a natural planktonic community of the Mediterranean Thau Lagoon. Mar Ecol Prog Ser 205: 171-184

Feuillet-Girard M, Héral M, Abrioux MF, Fontugne M (1994) Carbone organique dissous et particulaire de la colonne d'eau et de l'interface eau-sédiment du bassin de Marennes-Oléron: influence des huîtres. Oceanol Acta 17: 271-284

Fiala-Medioni A, Copello M, Colomines JC (1983) Relations trophiques entre huitre et milieu; influence de la concentration et de la taille des particules. Congrés: Bases biologiques de l'aquaculture, Actes de colloques No. 1. IFREMER, Montpellier, p 63-74

Frikha MG, Linley EAS, Delmas D (1987) Evolution annuelle et saisonnière de la microbiomasse d'une claire à huîtres: importance des populations bactérioplanctoniques. Oceanis 13:433-447

Frontier S (1985) Diversity and structure in aquatic ecosystems. Oceanogr Mar Biol Annu Rev 23:253-312

Gifford DJ, Dagg MJ (1991) The microzooplankton-mesozooplankton link: consumption of planktonic protozoa by the calanoid copepods Acartia clausi Dana and Neocalanus plumchrus Murukawa. Mar Microb Food Webs 5:161-177

Goulletquer Ph, Héral M (1997) Marine molluscan production trends in France: from fisheries to aquaculture. NOAA Tech Rep NMFS 129:137-164

Granéli E, Carlsson P, Legrand C (1999) The role of C, N and $\mathrm{P}$ in dissolved and particulate organic mattern as a nutrient source for phytoplankton growth, including toxic species. Aquat Ecol 33:17-27

Haas LW (1982) Improved epifluorescence microscopy for observing planktonic microorganisms. Ann Inst Océanogr 58:261-266

Hartmann HJ, Taleb H, Aleya L, Lair N (1993) Predation on ciliates by the suspension-feeding calanoid copepod Acanthodiaptomus denticornis. Can J Fish Aquat Sci 50: 1382-1393

Havskum H, Riemann B (1996) Ecological importance of bacterivorous, pigmented flagellates (mixotrophs) in the Bay of Aarhus, Denmark. Mar Ecol Prog Ser 137:251-263

Hawkins AJS, Bayne BL, Bougrier S, Héral M, Iglesias JIP, Navarro E, Smith RFM, Urrutia MB (1998) Some general relationships in comparing the feeding physiology of suspension-feeding bivalve molluscs. J Exp Mar Biol Ecol 219:87-103

Héral M (1985) Evaluation of the carrying capacity of molluscan shellfish ecosystems. Aquaculture. Shellfish culture development and management. International Seminar, La Rochelle 4-9 mars 1985. IFREMER, Brest, p 297-318

Héral M, Deslous-Paoli JM, Prou J, Razet D (1987) Relations entre la nourriture disponible et la production de mollusques en milieu estuarien: variabilité temporelle de la colonne d'eau. Haliotis 16:149-158 
Jones HLJ, Durjun P, Leadbeater BSC, Green JC (1995) The relationship between photoacclimatation and phagotrophy with respect to chlorophyll $a$, carbon and nitrogen content, and cell size of Chrysochromulina brevifilum (Prymnesiophyceae). Phycologia 34:128-134

Jonsson PR, Tiselius P (1990) Feeding behaviour, prey detection and capture efficiency of the copepod Acartia tonsa feeding on planktonic ciliates. Mar Ecol Prog Ser 60:35-44

Kemp PF, Newell SY, Krambeck C (1990) Effects of filterfeeding by the ribbed mussel Geukensia demissa on the water-columm microbiota of a Spartina alterniflora saltmarsh. Mar Ecol Prog Ser 59:119-131

Klaveness D (1992) Augmentation of the food supply for oyster larvae via bacterivorous flagellates: possible implications for larval breeding and oyster pond management. Aquacult Fish Manage 23:591-597

Korringa P (1976) Farming the cupped oysters of the genus Crassostrea. A multidisciplinary treatise. Developments in aquaculture and fisheries science, Vol 2. Elsevier Scientific Publ Co, Amsterdam, p 1-224

Kreeger DA, Newell RIE (1996) Ingestion and assimilation of carbon from cellulolytic bacteria and heterotrophic flagellates by the mussels Geukensia demissa and Mytilus edulis (Bivalvia, Mollusca). Aquat Microb Ecol 11:205-214

Leakey RJG, Burkill PH, Sleigh MA (1994) A comparison of fixatives for the estimation of abundance and biovolume of marine planktonic ciliate populations. J Plankton Res 16: 375-389

Le Gall S, Bel Hassen M, Le Gall P (1997) Ingestion of a bacterivorous ciliate by the oyster Crassostrea gigas: protozoa as a trophic link between picoplankton and benthic suspension-feeders. Mar Ecol Prog Ser 152:301-306

Loret P (1999) Le régime alimentaire et la sélection des particules chez l'huitre perlière Pinctada margaritifera dans le lagon de Takapoto (Tuamotu, Polynésie française). Thèse, Université de Polynésie Française

Neveux J, Lantoine F (1993) Spectrofluorometric assay of chlorophylls and phaeopigments using the least squares approximation technique. Deep-Sea Res 40:1747-1765

Newell CR, Shumway SE, Cucci TL, Selvin R (1989) The effects of natural seston particle size and type on feeding rates, feeding selectivity and food resource availibility for the mussel Mytilus edulis Linnaeus, 1758 at bottom culture sites in Maine. J Shellfish Res 8:187-196

Pastoureaud A, Héral M, Prou J, Razet D, Russu P (1996) Particle selection in the oyster Crassostrea gigas (Thunberg) studied by pigment HPLC analysis under natural food conditions. Oceanol Acta 19:79-87

Pielou EC (1975) Ecological diversity. Wiley, New York

Porter KG, Feig YS (1980) The use of DAPI for identifying and counting aquatic microflora. Limnol Oceanogr 25: 943-948

Porter KG, Pace ML, Battey JF (1979) Ciliate protozoans as links in freshwater planktonic food chains. Nature 277: 563-565

Putt M, Stoecker DK (1989) An experimentally determined carbon:volume ratio for marine 'oligotrichous' ciliates from estuarine and coastal waters. Limnol Oceanogr 34: 1097-1103

Riemann B, Sørensen HM, Bjørnsen PK, Horsted SJ, Jensen LM, Nielsen TG Søndergaard M (1990) Carbon budgets of the microbial food web in estuarine enclosures. Mar Ecol Prog Ser 65:159-170

Editorial responsibility: Fereidoun Rassoulzadegan, Villefranche-sur-Mer, France
Riera P, Richard P (1996) Isotopic determination of food sources of Crassostrea gigas along a trophic gradient in the estuarine bay of Marennes-Oléron. Estuar Coast Shelf Sci 42:347-360

Riisgård HU (1988) Efficiency of particle retention and filtration rate in 6 species of North East American bivalves. Mar Ecol Prog Ser 45:217-223

Robert JM (1983) Fertilité des eaux des claires ostréicoles et verdissement: utilisation de l'azote par les diatomées dominantes. Thèse de sciences, Université de Nantes

Robert JM, Maestrini SY, Dréno JP, Gonzalez-Rodriguez E (1979) Estimation au moyen de tests biologiques de la fertilité pour trois diatomées des eaux des claires à huîtres de Vendée. Oceanol Acta 2:275-286

Sherr EB, Caron DA, Sherr BF (1994) Staining of heterotrophic protists for visualisation via epifluorescence microscopy. In: Kemp PF, Sherr BF, Sherr EB, Cole JJ (eds) Handbook of methods in aquatic microbial ecology. Lewis Publishers, Boca Raton, p 213-227

Shumway SE, Cucci TL, Newell RC, Yentsch CM (1985) Particle selection, ingestion, and absorption in filter-feeding bivalves. J Exp Mar Biol Ecol 91:77-92

Sime-Ngando T, Gosselin M, Roy S, Chanut JP (1995) Significance of planktonic ciliated protozoa in the Lower St. Lawrence Estuary: comparison with bacterial, phytoplankton and particulate organic carbon. Aquat Microb Ecol 9:243-258

Sokal RR, Rohlf FJ (1981) Biometry, 2nd edn. Freeman, San Francisco

Sornin JM, Collos Y, Delmas D, Feuillet-Girard M, Gouleau D (1990) Nitrogenous nutrient transfer in oyster ponds: role of sediment in deferred primary production. Mar Ecol Prog Ser 68:15-22

Stenton-Dozey JME, Brown AC (1992) Clearance and retention efficiency of natural suspended particles by the rockpool bivalve Venerupis corrugatus in relation to tidal availability. Mar Ecol Prog Ser 82:175-186

Turpin V, Robert JM, Goulletquer P (1999) Limiting nutrients of oyster pond seawaters in the Marennes-Oléron region for Haslea ostrearia: applications to the mass production of the diatom in mesocosm experiments. Aquat Living Resour 12:335-342

Underwood AJ (1981) Techniques of analysis of variance in experimental marine biology and ecology. Oceanogr Mar Biol Annu Rev 19:513-605

Vahl O (1972) Efficiency of particle retention in Mytilus edulis L. Ophelia 10:17-25

Warwick RM (1986) A new method for detecting pollution effects on marine macrobenthic communities. Mar Biol 92: 557-562

Warwick RM, Clarke KR (1994) Relearning the ABC: taxonomic changes and abundance/biomass relationship in disturbed benthic communities. Mar Biol 118:739-744

Wright SW, Jeffrey SW, Mantoura RFC, Llewellyn CA, Bjornland T, Repeta D, Welschmeyer N (1991) Improved HPLC method for analysis of chlorophylls and carotenoids from marine phytoplankton. Mar Ecol Prog Ser 77:183-196

Zanette Y (1980) Intervention de quelques facteurs dans l'évolution de la biomasse des claires de MarennesOléron. Cons Inst Explor Mer 45

Zurburg W, Smaal AAD, Héral M, Danker N (1994) Seston dynamics and bivalve feeding in the bay of MarennesOléron (France). Neth J Aquat Ecol 26:459-466

Submitted: November 19, 1999; Accepted: June 21, 2000

Proofs received from author(s): September 6, 2000 